\title{
Antitumor Effect of Cationic INKKI Peptide from Bovine $\beta$-Casein on Melanoma B16F10*
}

\author{
Ricardo Alexandre Azevedo, Adilson Kleber Ferreira, Aline Vivian Vatti Auada, \\ Kerly Fernanda Mesquita Pasqualoto, Rafael Marques-Porto, Durvanei Augusto Maria, \\ Ivo Lebrun ${ }^{\#}$
}

Butantan Institute, Biochemistry and Biophysical Laboratory, Sao Paulo, Brazil.

Email: *lebrun@butantan.gov.br

Received May $30^{\text {th }}, 2012$; revised June $30^{\text {th }}, 2012$; accepted July $11^{\text {th }}, 2012$

\begin{abstract}
Cationic peptide with the sequence INKKI 41-45 was isolated from bovine $\beta$-casein after tryptic hydrolysis and synthetized. The aim of this work was to evaluate the antiproliferative activity in vitro and antitumor effect in animal model. The in vitro cytotoxicity was evaluated on B16F10 melanoma cells by MTT assay. Detection of apoptosis was measured using the annexin V/PI double staining and cell cycle analysis performed flow cytometry. Caspase-3 activity was analyzed with substrate specific fluorogenic DEVD-MCA. In vivo, antitumor activity was evaluated in B16F10 melanoma tumor-bearing C57BL/6J mice. The animals were treated with $55 \mathrm{mg} / \mathrm{kg}$ INKKI administered into peritumoral region, while control group received saline solution. The following antitumor parameters were examined: tumor volume, number of metastases, tumor delayed time, tumor doubling time. Histological analyses were performed with $\mathrm{H} \& \mathrm{E}$ staining. The results showed that INKKI induced dose-response cytotoxicity selective for B16F10 melanoma cells (IC50 $1.7 \mu \mathrm{M}$ ) and did not present cytotoxic effects for FN1 fibroblast cells. INKKI-induced apoptosis detected trough of annexin V/PI assay and it was accompanied with an increase of sub-G1 apoptotic fractions and significant increase of caspase-3 cleavage. The tumor-bearing mice treated with INKKI showed a significant reduction in tumor volume of $72.62 \%$ and decreased of metastasis number loci. In addition, INKKI caused a significant delay in tumor growth and prolonged the tumor doubling time. Histological analysis revealed an increased of necrosis areas and reduction of tumor cells in tumor treated with INKKI, it was a many hallmark of its antitumor effects observed from in vivo experiments. In conclusion, we show that INKKI is a peptide that could be considered a new putative candidate development to anticancer therapy drug.
\end{abstract}

Keywords: $\beta$-Casein Peptide; Apoptosis; Metastasis; Tumor Growth; Melanoma

\section{Introduction}

Cancer is a leading cause of mortality worldwide, representing about one-eighth of all deaths. Its incidence is strongly affected by demographic aspects such as aging of the population, feeding habits, etc., and, especially, ambient factors such as UV incidence. Furthermore, cancer has also emerged as a major public health problem in developing countries. The World Health Organization estimated that the number of new cases of cancer will continue rising and by 2030 death rates will reach 11 million deaths per year [1,2]. Melanoma is a low incidence cancer and, although representing only $4 \%$ of all dermatologic cancers, it is very aggressive with a bad prognosis in the metastatic stage and is responsible for $80 \%$ of total skin cancer deaths [2]. The discovery of new anticancer

\footnotetext{
${ }^{*}$ Conflict of interest statement: None to declare for all authors.
}

${ }^{*}$ Corresponding author. agents can provide better alternatives to existing treatments against tumors. Although much progress has been described in the development of cancer therapies in recent decades, problems continue to arise particularly with respect to chemotherapy due to tumor resistance and low specificity, requiring the search and development new more specific drugs $[3,4]$.

Cationic peptides have been studied recently as potential anticancer agents or templates. They have the ability to selectively permeabilize biological membranes of tumor cells, probably due to an interaction with the negatively charged tumor cell surface [5]. The peptides called $\beta$-casochemotide- 1 have been reported as having high antitumor activity. One of these peptides obtained from $\beta$ bovine casein, showed a potent chemotactic activity in macrophages and monocytes [6]. The inhibition of tumor growth by milk proteins and the peptides resulting from their hydrolysis is associated with the stimulation of the 
immune system, such as T lymphocyte proliferation, increase in natural killer cell (NK) activities, and expansion of the population of cytotoxic T lymphocytes [7].

Other peptides also play antitumor activity, such as $\alpha$ Lactalbumin. A structural derivative of $\alpha$-lactalbumin possesses anti-tumor properties and is called human $\alpha$-Lactalbumin Made Lethal to Tumor Cell (HAMLET) [8-11]. Since the first description of HAMLET's tumor-selective apoptotic activities, two clinical trials have been successfully carried out. HAMLET was showed to be active against skin papillomas and bladder cancer, whereas no side effects to adjacent healthy tissue could be observed [12$16]$.

In a recent study, we hydrolyzed $\beta$-casein with trypsin and isolated the peptide INKKI corresponding to residues 41 - 45 of the protein. We showed that this peptide presents in vitro immunomodulatory activity such as an increase of the release of $\mathrm{H}_{2} \mathrm{O}_{2}$ and phagocytic capacity of mice resident macrophages $[17,18]$. Other authors have shown that the fragment $1-28$ of bovine $\beta$-casein also exhibits enhanced proliferation and IL- 6 expression by mouse CD19+ cells [19].

Based on the recent reports on the antitumor activity of cationic peptides, the aim of the present study was to evaluate antitumor effects of INKKI, derived from the bovine $\beta$-casein, on melanoma model.

\section{Materials and Methods}

\subsection{INKKI Peptide}

The peptide INKKI was previously isolated from bovine $\beta$-casein by HPLC. The sequences were confirmed by amino acid analysis and also by mass spectrometry on a triple quadrupole Micromass mass spectrometer, model Quatro II (Micromass, Milford, MA, USA). After primary sequence determination, the peptides were synthesized by solid phase peptide synthesis and sequenced using Edman degradation. The natural and synthetic peptides were compared by MALDI-TOF. The synthetic peptides were chemically and biologically identical as described in previous works [17,18]. The hydrophobic/hydrophilic balance of INKKI was also calculated considering neutral and ionized forms. The n-octacnol/water partition coefficients, $\mathrm{Clog} P$ (neutral) and $C \log \mathrm{D}$ (ionization), which expressed this kind of nonpolar/polar equilibrium, were calculated employing the Marvin-Calculator Plugins software available from http://www.chemaxon.com [19-21].

\subsection{Cell Culture}

The B16F10 (murine malignant melanoma ATCC ${ }^{\circledR}$ CRL6475) cells were obtained from the American Type Culture Collection (Mannasa, VA, USA). FN1 (normal hu- man fibroblasts) cells were obtained from the laboratory of Biochemistry and Biophysics (Butantan Institute, SP, Brazil). All cells were cultured in RPMI-1640 medium (GIBCO) supplemented with $10 \%$ fetal bovine serum (FBS), $100 \mu \mathrm{g} / \mathrm{ml} \mathrm{L}$-glutamine, $100 \mathrm{U} / \mathrm{ml}$ penicillin and $100 \mu \mathrm{g} / \mathrm{ml}$ streptomycin in culture flasks at $37^{\circ} \mathrm{C}$ in a humid atmosphere containing $5 \% \mathrm{CO}_{2}$.

\subsection{Measurement of Cytotoxicity Activity}

The cytotoxicity study was performed when cell growth reached $80 \%-90 \%$ confluence. The cells were then seeded into 96 well plates at a density of $1 \times 10^{4}$ cells/well. Briefly, B16F10 and FN1 cells were plated in triplicate and incubated overnight at $37^{\circ} \mathrm{C}$ in a humidified incubator containing $5 \% \mathrm{CO}_{2}$. After this, the cells were treated with concentrations of $20 \mu \mathrm{M}$ to $0.03 \mu \mathrm{M}$ INKKI. After $24 \mathrm{~h}$ of treatment, cells were exposed to $5 \mathrm{mg} / \mathrm{ml}$ MTT for $2 \mathrm{~h}$ and the precipitated formazan was dissolved in $0.1 \mathrm{~N} \mathrm{HCl}$ in isopropanol. The IC50 values were determined and measured at $540 \mathrm{~nm}$ on a microplate reader Thermo Plate (Rayto Life and Analytival Sciences C. Ltd, Germany).

\subsection{Detection of Apoptotic Cells}

The proportion of apoptotic cells was estimated by double staining with Annexin V-fluorescein isothiocyanate (FITC) (Boehringer-Mannheim GmbH, Mannheim, Germany) and propidium iodide-(PI) (Sigma-Aldrich, St Louis, MO, USA). B16F10 cells at a concentration of $1 \times 10^{6}$ cells were treated for $24 \mathrm{~h}$ with $1.7 \mu \mathrm{M}$ INKKI and untreated cells were considered as control. After this period the cells were stained with $4 \mu \mathrm{g} / \mathrm{ml}$ Annexin $\mathrm{V}$ and 18 $\mu \mathrm{g} / \mathrm{ml}$ PI for $1 \mathrm{~h}$ at $37^{\circ} \mathrm{C}$. Stained cells were analyzed by flow cytometry in a FACSCalibur (Becton Dickinson Immunocytometry, San Jose, CA, USA), and the data were analyzed with the software WinMDI 2.6 (Scripps Institute, La Jolla, CA, USA).

\subsection{Evaluation of Caspase 3 Activity}

Aliquots of $100 \mu \mathrm{l}\left(1 \times 10^{6}\right)$ of the B16F10 cells were treated with $1.7 \mu \mathrm{M}$ INKKI and untreated cell were considered as control. Cells were washed 3 times with Krebs Ringer (124 mM NaCl, 4 mM KCl, $\mathrm{MgSO}_{4} 1.2 \mathrm{mM} \mathrm{Na}$ Hepes $25 \mathrm{mM}$ glucose and $12 \mathrm{mM} \mathrm{CaCl}_{2} 1 \mathrm{mM}, \mathrm{pH}$ 7.4). The samples were lysed in PBS $\left(\mathrm{Na}_{2} \mathrm{HPO}_{4} 0.0004 \mathrm{mg} / \mathrm{ml}\right.$, $\mathrm{NaCl} 0.008 \mathrm{mg} / \mathrm{ml}, \mathrm{KCl} 0.0002 \mathrm{mg} / \mathrm{ml}, \mathrm{pH}$ 7.4) with triton $\mathrm{X}-1000.2 \%$ for the test with the fluorogenic substrate DEVD-MCA (Peptide Institute), specific for caspase-3. The kinetics of hydrolysis of the substrate was monitored in a microplate fluorometer, with excitation at $370 \mathrm{~nm}$ and emission at $460 \mathrm{~nm}$. The results are expressed in $\mathrm{v} / \mathrm{max}$ of substrate hydrolyzed per minute. 


\subsection{Cell Cycle Analysis}

B16F10 cells previously treated with $1.7 \mu \mathrm{M}$ INKKI and untreated cells, considered as control, were harvested, washed with PBS and resuspended in $300 \mu \mathrm{l}$ of trypsin $0.03 \mathrm{~g} / \mathrm{l}, 10 \mathrm{mM}$ Tris $(\mathrm{pH} 8.0)$. After $15 \mathrm{~min}$ of incubation at room temperature, the neutralization solution (tripsin inhibitor $0.5 \mathrm{~g} / \mathrm{l}$, RNase A $0.1 \mathrm{~g} / 1$ and spermine $1.2 \mathrm{~g} / \mathrm{l}$ ) was added and incubation continued for $15 \mathrm{~min}$. Pelleted cells were resuspended in $0.3 \mathrm{ml}$ PBS and fixed by addition of ice-cold ethanol (70\%). Prior to analysis, cells were incubated with $18 \mathrm{mg} / \mathrm{ml}$ propidium iodide solution and incubated in the dark for $30 \mathrm{~min}$. Flow cytometry analysis was performed on a FACScan flow cytometry system (Scalibur-Becton Dickinson, San Jose, $\mathrm{CA})$. The DNA content in the cell cycle phases $(\mathrm{G} 0 / \mathrm{G} 1$, $\mathrm{S}$ and $\mathrm{G} 2 / \mathrm{M}$ ) was analyzed by the Cell-Quest software and by the Modfit software cell (Becton, Dickinson, NJ, USA).

\subsection{Inoculation of Mice with B16F10 Melanoma Cells}

The B16F10 cells were maintained according to protocol of the cell culture. Adherent cells were detached from plates with $0.1 \%$ trypsin and $0.2 \%$ EDTA. After trypsin inactivation with $10 \% \mathrm{FBS}$, viable cells were counted based on trypan blue dye exclusion method. For the in vivo experiments $5 \times 10^{4}$ cells suspended in $100 \mu \mathrm{l}$ of PBS were injected subcutaneously (s.c) in the flanks of C57BL/6J mice.

\subsection{Antitumor Activity}

Mice previously were inoculated with B16F10 melanoma cells as described above. $24 \mathrm{~h}$ after tumor implantation, the animals were randomized and divided into different groups $(n=5)$. Animals were treated with administration into the peritumoral region of $55 \mathrm{mg} / \mathrm{kg}$ INKKI and saline for the control group, the treatment continued for 21 days. The tumor sizes were measured three times a week using a caliper-like instrument during the experiment, and converted to tumor weight by the equation: tumor weight $=($ length $2 \times$ width $) / 2$. We also evaluated the tumor growth delayed and tumor doubling time.

All experiments were performed according to institutional ethics commission guidelines concerning the protection of animals used for experimentation and based no the current international procedure rules in animal care and handling (protocol number 349/06 CEUAIBU).

\subsection{Histological Analysis}

Tumor tissue of the mice previously treated with $1.7 \mu \mathrm{M}$ INKKI and saline solution mice, considered as control were fixed in $10 \%$ buffered formalin and routinely pro- cessed for paraffin embedding. Sections of $5 \mu \mathrm{m}$ were obtained and stained with Hematoxylin-Eosin.

\subsection{Statistical Analysis}

The results were expressed as the mean value \pm standard deviation (SD). Statistics analysis was carried out with Student's t test and analysis of variance (ANOVA) using the Instat, version 2.0, program, with the level of significance set at $* p<0.05, * * p<0.01$ and $* * * p<0.001$.

\section{Results}

\subsection{Biochemical Characteristics of INKKI}

INNKI corresponds to residues 41 - 45 of the bovine $\beta$-casein sequence, and presents a non-polar isoleucine residue at each extremity, which can be visualized by a green to blue color on the molecular surface. The two lysine residues confer positive net charge to the peptide. Asparagine and two lysine residues are responsible for the most hydrophilic feature of this peptide (intense blue regions on surface (Figure 1), and the negative values obtained for $\mathrm{C} \log \mathrm{P}(-1.77)$ and $\mathrm{C} \log \mathrm{D}(-4.36)$ corroborate this finding.

\subsection{INKKI Induces a Citotoxic Effect on B16F10 Cells}

The first step in order to evaluate a potential antitumor activity of the peptide was to perform an MTT assay. INKKI had no effect on the viability of FN1 cells. On the other hand, after $24 \mathrm{~h}$ of treatment, INKKI exhibited a potent activity against B16F10 cells (IC50 $1.7 \mu \mathrm{M})$. These results suggest a preferential activity of INKKI on tumor cells (Figures 2(a)-(b)).

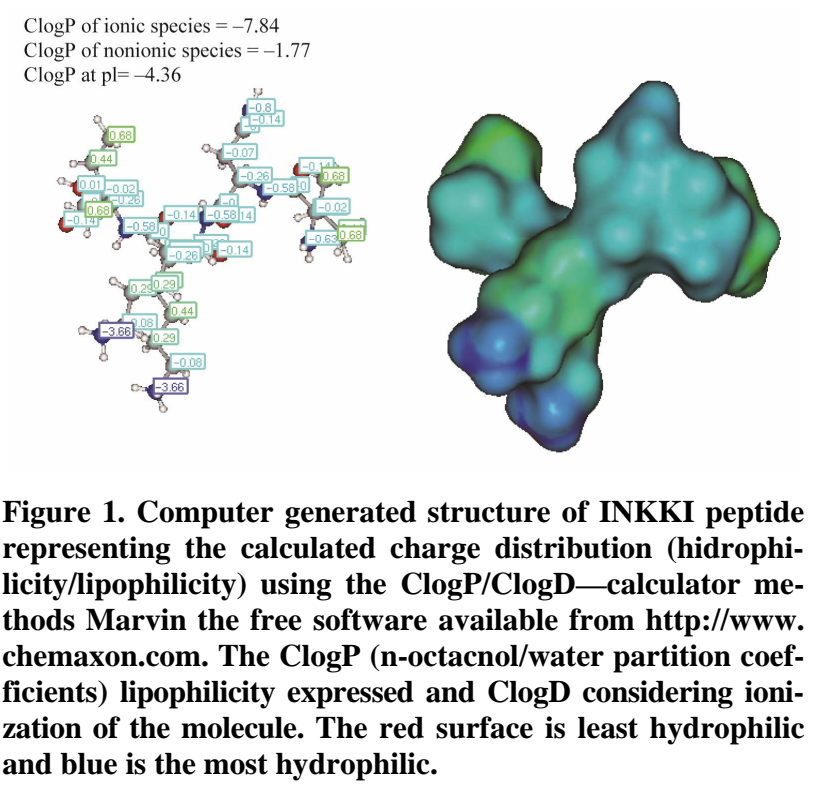

Figure 1. Computer generated structure of INKKI peptide representing the calculated charge distribution (hidrophilicity/lipophilicity) using the $C \log P / C \operatorname{logD}$ - calculator methods Marvin the free software available from http://www. chemaxon.com. The ClogP (n-octacnol/water partition coefficients) lipophilicity expressed and ClogD considering ioniand blue is the most hydrophilic. 

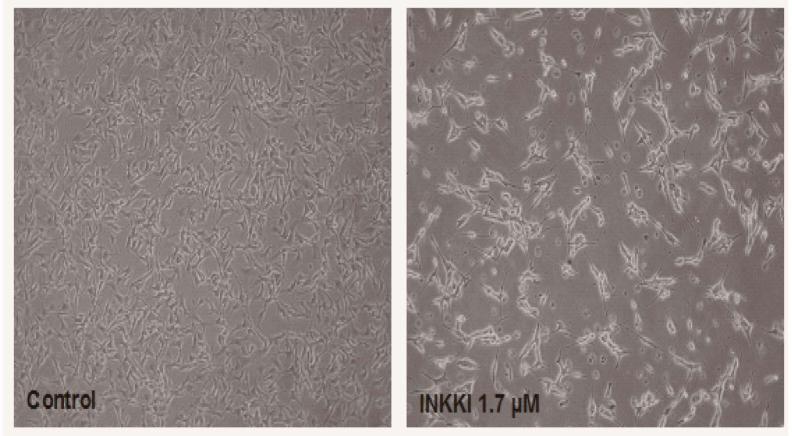

(a)

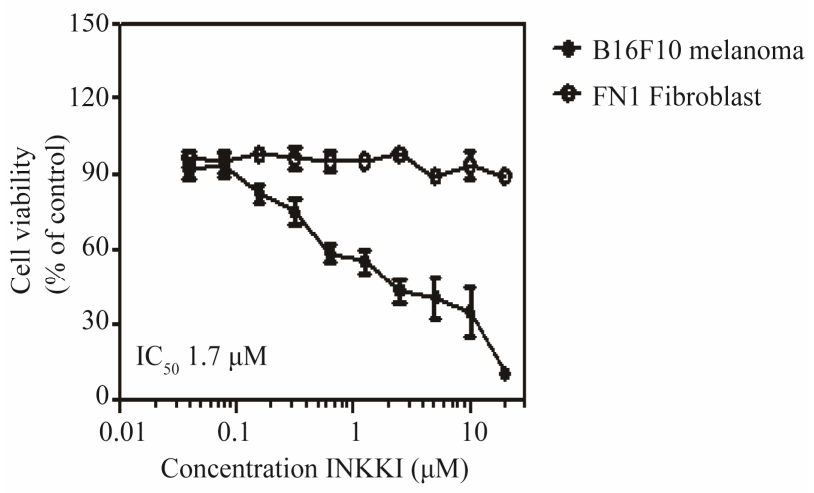

(b)

Figure 2. MTT assay showing cell viability of B16F10 and FN1 cells in response to INKKI. Cells were exposed to various concentrations of the peptide, for $24 \mathrm{~h}$. (a) Morphological changes of B16F10 were observed under the inverted phase-contrast microscope (magnification, $\times 200)$; (b) Each point represents the mean of four determinations. Cell viability was assessed with the activity of untreated cells taken as $\mathbf{1 0 0} \%$. Data are the mean \pm S.D. of three different experiments performed in triplicate.

\subsection{INKKI Induces Caspase- 3 Mediated Apoptosis in B16F10 Cells}

The fact that most cells were in the sub-G1 peak indicated that they were dying. To verify if the cells were undergoing an apoptotic process, we used annexin V. The cells were stained with two cell markers, annexin $\mathrm{V}$, to measure phosphatidylserine translocation to the extra-cellular leaflets (early apoptosis), and PI to measure the loss of phospholipid membrane integrity (late apoptosis/necrosis). The treatment of the B16F10 murine malignant melanoma cells with INKKI at $1.7 \mu \mathrm{M}$ concentration resulted in an $82.82 \% \pm 8.56$ increase of apoptotic cells as compared with the control $(3.99 \% \pm 1.2$ apoptotic cells) (Figure 3(a)). These data suggest that INKKI is highly effective in controlling tumor progression by apoptosis (Figure 3(b)). To confirm the annexin V assay, we performed a fluorometric analysis that showed that INKKI induces apoptosis probably mediated by the increase of caspase- 3 activity (Figure 3(c)).

\subsection{INKKI Inhibits Cell Proliferation by Decreasing the Number of Cells in the G2/M Phase}

We then analyzed the effect of the peptides on the cell cycle. After $12 \mathrm{~h}$ of treatment with INKKI at $1.7 \mu \mathrm{M}$, showed a significant $(* * * p<0.001)$ increase in the median percentage of apoptotic cells as evidenced by the sub-G1 peak, as compared to the untreated cells. In addition, the proportion of cells in $\mathrm{G} 2 / \mathrm{M}$ phases decreased. These data suggest that INKKI mediate antiproliferative and proapoptotic effects on B16F10 cells (Figure 3(d)).

\subsection{INKKI Inhibits Metastasis and Decreases Tumor Volume}

All previous results were obtained in vitro. To evaluate the in vivo effect, the peptide was injected in the peritumoral region of mice bearing B16-F10 melanoma cells. INKKI reduced significantly $(78.8 \%)$ the tumor volume as compared to the control animals (Figures 4(a)-(b)). Histological analysis revealed an increase of necrosis areas and reduction of tumor cells in tumor treated with INKKI, it was a many hallmark of its antitumor effects observed from in vivo experiments (Figure 4(c)). The mice treated with $55 \mathrm{mg} / \mathrm{kg}$ of INKKI presented inhibition of total metastasis $(72.62 \% \pm 3.7 \%)$ in comparison with the control group (Figure 5(a)). Mice treated only with saline showed increased metastasis (average of $84.5 \% \pm$ $5.2 \%$ ), located mainly in the lung, lymph node and spleen (Figure 5(b)). In addition, the tumor volume measurements allowed calculate the tumor growth delay and tumor doubling time. In agreement with the reduction of tumor volume, the treatment with INKKI caused an increase of the tumor doubling time and tumor growth delay, i.e., the time for the tumor to reach at $1 \mathrm{~cm}^{3}$ (Figures 5(c)-(d)).

\section{Discussion}

Recent research aiming the development of new anticancer agents focused mainly in the utilization of peptides presenting antitumor effects have been published with encouraging results [5-7]. It is known that a variety of peptides show a selective cytotoxic activity against tumor cells [22-24]. Among them, bioactive peptides hydrolytically originated from proteins, known as cryptides, are especially promising $[25,26]$. We have previously reported that peptides obtained by the hydrolysis of casein present a number of different activities in various biological systems. However, the precise mechanisms of cytotoxic effects remain unclear [7]. Here we investigated the effects of INKKI, from hydrolyzed $\beta$-casein, on the B16 F10 tumor cell model.

The data from the initial MTT experiment showed, interestingly, that INKKI presented a selective cytotoxic 


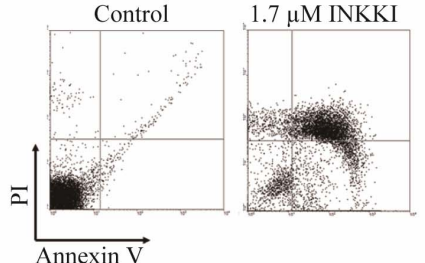

(a)

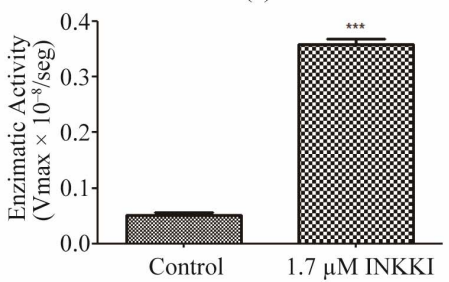

(c)

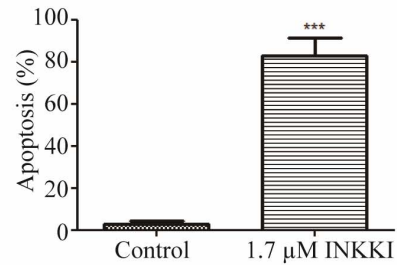

(b)

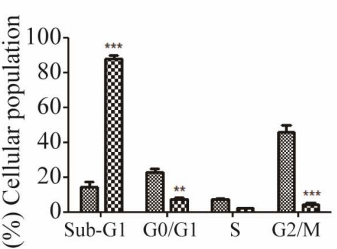

(d)

Figure 3. INNKI mediated cell death in B16F10 cells. (a) Dot plots representative of apoptotic effects of INKKI with annexin V/PI staining by flow cytometry; (b) Quantification of the data presented in dot plots for cells undergoing apoptosis; (c) Caspase-3 activity was measured after $6 \mathrm{~h}$ of exposure to the peptide, by cleavage of the fluorescent peptide substrate DEVD-MCA; (d) Propidium iodide staining followed of analysis of DNA content by flow cytometry on the Becton Dickinson FACScan. Data are the means \pm S.D. of three different experiments performed in duplicate. $*^{*} p<0.01$ and ${ }^{* * *} p<0.001$; statistically significant.

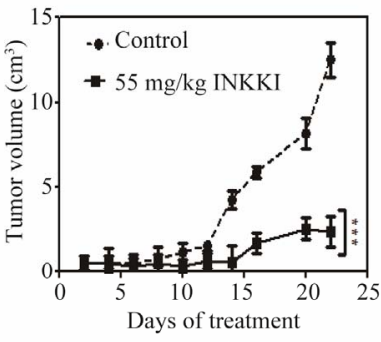

(a)

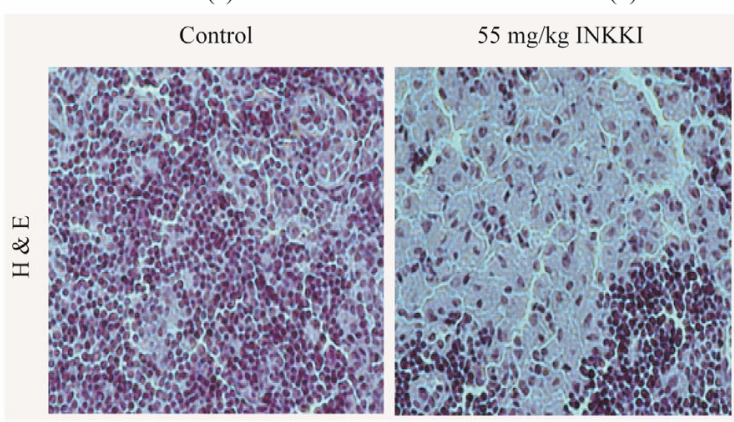

(c)

Figure 4. Peptide effects on tumor volume in mice bearing-melanoma B16F10 melanoma. Twelve days after tumor implantation, the mice $\mathrm{C} 57 \mathrm{BL} / 6 \mathrm{~J}(\mathrm{n}=5)$ were treated daily in the peri-tumoral region with $55 \mathrm{mg} / \mathrm{kg}$ INKKI for fifteen days. (a) The size of tumors was then measured in alternate days for 21 days, using three dimensional measurements (length2 $\times$ width)/2; (b) The control animals showed an increase of the tumor mass, whereas animals treated with $55 \mathrm{mg} / \mathrm{kg}$ INKKI presented inhibition of tumor growth; (c) Representative photomicrographs of tumor sections stained with hematoxylin-eosin (magnification, $\times 200$ ). The control showed large density of tumor cells while animals treated with $55 \mathrm{mg} / \mathrm{kg}$ INKKI presented an increase of the necrotic area and consequently reducing the density of tumor cells.
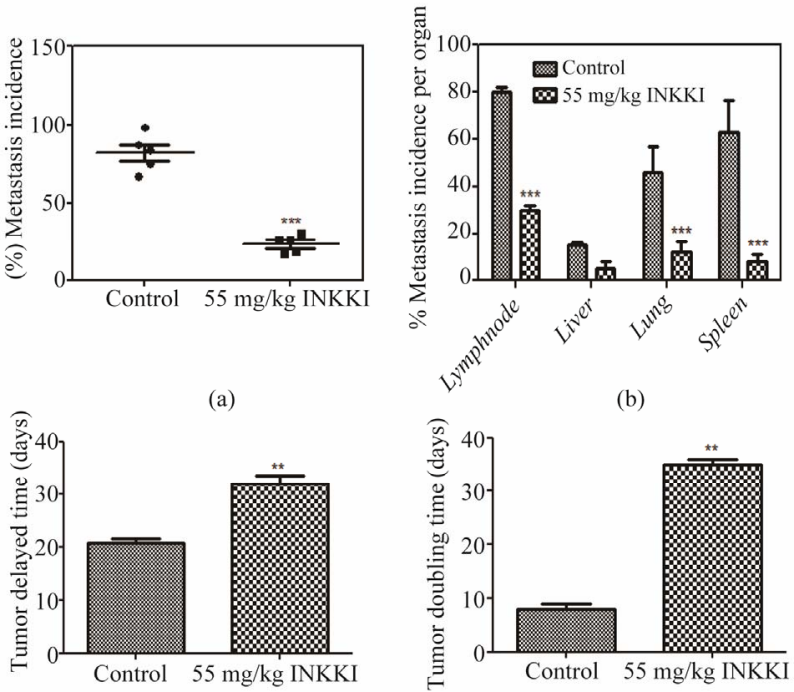

(c)

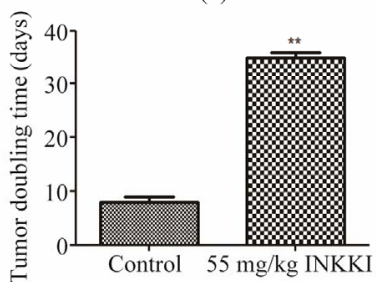

(d)

Figure 5. After the treatment, the mice were sacrificed and the global incidence and average number of metastases per organ were counted. (a) INKKI reduced the number of metastatic foci as compared with the control animals; (b) The treatment with $55 \mathrm{mg} / \mathrm{kg}$ INKKI reduced the average number of metastases per organ; (c) The treatment with INKKI caused an increase of the tumor growth delay; (d) Additionally INKKI presented a significant increase in tumor doubling time. All values are expressed as averages \pm S.D. of multiple determinations. $* * p<0.01$ and $* * * p<0.001$ compared with untreated statistically significant.

activity in B16F10 cells, while no effect was observed in normal fibroblast. We hypothesized that the cationic properties of INKKI might increase its binding to the tumor cells surface, increasing its selectivity. The hypothesis is 
supported by the fact that tumor cell membranes present several alterations, such as glycoproteins and glycolipids as well as an increase in sialylation. These changes make the cell surface more negative, increasing the affinity for positive peptides. These modifications can give to the cell tumor membrane a negative charge, which enhanced the binding of cationic peptide [27-31].

In order to better understand the cytotoxic effects of INKKI, we investigated the possibility of an apoptotic mechanism. INKKI was able to induce apoptosis in B16F10 cells in a caspase-dependent manner as revealed by the fluorometric assay with the cleavage of the specific substrate DECD-MCA. These data show that INKKI induces apoptosis and suggest that it occurs through the mitochondrial pathway, since caspace- 3 is a cysteine protease involved in apoptosis, inducing the cleavage of substrates such as cytoskeleton proteins, leading to the typical morphological changes of apoptosis. INKKI presents $60 \%$ homology and similar biochemical characteristics to Mastoparan, a pro-apoptotic 14 amino-acid amphipathic peptide. In a recent study [32,33], Mastoparan has been shown to induce mitochondrial permeability transition and apoptosis in tumor cells, comparable to our results with INKKI $[34,35]$.

Based on our in vitro experiments, we tested INKKI in a well-characterized in vivo model of melanoma to evaluate the therapeutic potential of this peptide. The treatment of tumor-bearing mice with INKKI induced an inhibition of tumor growth. An essential part in melanoma therapeutics is the ability to eliminate metastasis, improving the quality of life of the patients [31]. Our investigation confirms that INKKI reduces the spreading of nodules in several organs such as the liver parenchyma and satellite lymph nodes. These results suggest that the peptide has anti-metastatic activity. Nonetheless, further studies are required to define the pathway for its action mechanism. Of interest, the inhibitory effect of INKKI on tumor growth delay (Figure 4(d)) is more effective (33 days) when compared to the control (20 days). Accordingly, tumor doubling time was significantly increased by INKKI. In addition, the histological analysis that INKKI reduced the tumor cell density in the tumoral micro-environment. An extensive necrotic area replaced the dead cells. These results are critically important, due to the antitumor effectiveness of INKKI, since it mimics clinical conditions of an eventual future clinical trial. In conclusion, our results demonstrate that the peptide INKKI, corresponding to $\beta$-casein residues $41-45$, showed besides an in vitro effect on B16F10 cells with a cytotoxic effect showed also a significant effect to produce antitumor effects in vivo. The present investigation suggests an effective biological use for this casein derived peptide to develop new putative agents for the fight against cancer.

\section{Acknowledgements}

Financial Support: FAPESP (Proc. 2010/51077-5), INCT Tox and CNPq.

\section{REFERENCES}

[1] S. Riedl, D. Zwytick and K. Lohner, "Membrane-Active Host Defense Peptides-Challenges and Perspectives for the Development of Novel Anticancer Drugs," Chemistry and Physics of Lipids, Vol. 164, No. 8, 2011, pp. 766-781. doi:10.1016/i.chemphyslip.2011.09.004

[2] A. L. Matsuo, A. S. Tanaka, M. A. Juliano, E. G. Rodrigues and L. R. Travassos, "A Novel Melanoma-Targeting Peptide Screened by Phage Display Exhitits Antitumor Activity," Journal of Molecular Medicine, Vol. 88, No. 12, 2010, pp. 1255-1264. doi:10.1007/s00109-010-0671-9

[3] A. K. Ferreira, R. Meneguelo, S. C. Neto, G. O. Chierice and D. A. Maria, "Synthetic Phosphoethanolamine Induces Apoptosis through Caspase-3 Pathway by Decreasing Expression of Bax/Bad Protein and Changes Cell Cycle in Melanoma," Journal Cancer Science \& Therapy, Vol. 3, No. 3, 2011, pp. 53-59.

[4] A. K. Ferreira, R. Meneguelo, S. C. Neto, A. Pereira, O. M. R. Filho, G. O. Chierice and D. A. Maria, "Anticancer Effects of Synthetic Phosphoethanolamine on Ehrlich Ascites Tumor: An Experimental Study," Anticancer Research, Vol. 32, No. 1, 2012, pp. 95-104.

[5] C. Araya and B. Lomonte, "Antitumor Effects of Cationic Synthetic Peptides Derived from Lys49 Phospholipase A2 Homologues of Snake Venoms," Cell Biology International, Vol. 31, No. 3, 2007, pp. 263-268.

doi:10.1016/j.cellbi.2006.11.007

[6] T. Kawahara, D. Katayama and H. Otani, "Effect of $\beta$ Casein (1-28) on Proliferative Responses and Secretory Functions of Human Immunocompetent Cell Lines," Bioscience, Biotechnology, and Biochemistry, Vol. 68, No. 10, 2004, pp. 2091-2095.

[7] P. W. Parodi, "A Role for Milk Proteins and Their Peptides in Cancer Prevention," Current Pharmaceutical Design, Vol. 13, No. 8, 2007, pp. 813-828. doi: $10.2174 / 138161207780363059$

[8] O. Hallgren, S. Aits, P. Brest, L. Gustafsson, A. K. Mossberg, B. Wult and C. Svanborg, "Apoptosis and Tumor Cell Death in Response to HAMLET (Human Alpha-Lactalbumin Made Lethal to Tumor Cells)," Advances in Experimental Medicine and Biology, Vol. 66, 2008, pp. 217 240. doi:10.1007/978-0-387-74087-4 8

[9] J. Fast, A. K. Mossberg, H. Nilsson, C. Svanborg, M. Akke and S. Linse, "Compact Oleic Acid in HAMLET," FEBS Letter, Vol. 579, No. 27, 2005, pp. 6095-6100. doi:10.1016/j.febslet.2005.08.089

[10] M. Svensson, A. Hakansson, S. Linse and C. Svanborg, "Conversion of Alpha-Lactlbumin to a Protein Inducing Apoptosis," Proceedings of the National Academy Science of the United States of America, Vol. 97, No. 8, 2000, pp. 4221-4226. doi:10.1073/pnas.97.8.4221

[11] A. K. Mossberg, B. Wullt, L. Gustafsson, W. Mansson, E. Ljunggren and C. Svanborg, "Bladder Cancers Respond 
to Intravesical Installation of HAMLET (Human $\alpha$-Lactalbumin Made Lethal to Tumor Cells)," International Journal of Cancer, Vol. 121, No. 6, 2007, pp. 1352-1359. doi:10.1002/ijc. 22810

[12] C. Köhler, V. Gogvadze, A. Häkansson, C. Svanborg, S. Orrenius and B. Zhivotovsky, "A Folding Variant of Human Alpha-Lactalbumin Induces Mitochondrial Permeability Transition in Isolated Mitochondrial," European Journal of Biochemistry, Vol. 268, No. 1, 2001, pp. 186191. doi:10.1046/j.1432-1327.2001.01870.x

[13] C. Düringer, A. Hamiche, L. Gustafsson, H. Kimura and C. Svanborg, "HAMLET Interacts with Histones and Chromatin in Tumor Cell Nuclei," Journal Biological Chemistry, Vol. 278, No. 43, 2003, pp. 42131-42135. doi:10.1074/jbc.M306462200

[14] S. Permyakov, I. V. Pershikiva, A. P. Zhadan, J. Goers, A. G. Bakunts, V. N. Uversku, L. J. Berliner and E. A. Permyakov, "Conversion of Human Alpha-Lactalbumin to an Apo-Like State in the Complexes with Basic Poly-Amino Acids: Toward Understanding of the Molecular Mechanism of Antitumor Action of HAMLET," Journal Proteome Research, Vol. 4, No. 2, 2005, pp. 564-569. doi:10.1021/pr0497778

[15] M. Hoyer-Hansen and M. Jäättelä, “Autophagy: An Emerging Target for Cancer Therapy," Autophagy, Vol. 4, No. 5, 2008, pp. 574-580.

[16] S. Aits, L. Gustafsson, O. Hallgren, P. Brest, M. Gustafsson, M. Trulsson, A. K. Mossberg, H. U. Simon, B. Mograbi and C. Svanborg, "HAMLET (Human Alpha-Lactalbumin Made Lethal to Tumor Cells) Triggers Autophagic Tumor Cell Death," International Journal of Cancer, Vol. 124, No. 5, 2009, pp. 1008-1019. doi:10.1002/ijc.24076

[17] E. A. Perpetuo, L. Juliano and I. Lebrun, "Biochemical and Pharmacological of Two Bradykinin-Potentiating Peptides Obtained from Tryptic Hydrolysis of Casein," Journal of Protein Chemistry, Vol. 22, No. 7-8, 2003, pp. 601-606. doi:10.1023/B:JOPC.0000008724.98339.ff

[18] I. Lebrun, V. Carvalho, L. Juliano, M. A. Juliano and M. C. de Souza e Silva, "Effects of 'Casoparan', a Peptide Isolated from Casein Hydrolysates with Mastoparan-Like Properties," Mediators Inflammation, Vol. 13, No. 4, 2004 , pp. 263-268. doi:10.1080/09629350400003068

[19] N. V. Vellarkad, K. G. Arup, R. R. Ganapathi and K. R. Roland, "Atomic Physicochemical Parameters for Three Dimensional Structure Directed Quantitative StructureActivity Relationships. 4. Additional Parameters for Hydrophobic and Dispersive Interactions and Their Application for an Automated Superposition of Certain Naturally Occurring Nucleoside Antibiotics," Journal Chemical Information Computer Science, Vol. 29, No. 3, 1989, pp. 163-172. doi:10.1021/ci00063a006

[20] K. Gilles, L. Ju-Yun, W. Shaomeng and D. Mario, "Computer Automated Log P Calculations Based on an Extended Group Contribution Approach," Journal Chemical Information Computer Science, Vol. 34, No. 4, 1994, pp. 752781. doi:10.1021/ci00020a009

[21] C. Ferenc, T. K. Anna, I. Panderi and D. Ferenc, "Prediction of Distribution Coefficient from Structure. 1. Estimation Method," Journal of Pharmaceutical Sciences, Vol.
86, No. 7, 1997, pp. 865-871. doi:10.1021/js960177k

[22] M. Asano, N. Nio and Y. Ariyoshi, "Inhibition of Prolyl Endopeptidase by Synthetic-Casein Peptides and Their Derivatives with a C-Terminal Prolinol or Prolinal," Bioscience Biotechnology Biochemistry, Vol. 56, No. 2, 1992, pp. 976-977. doi:10.1271/bbb.56.976

[23] J. S. Armstrong, "Mitochondria: A Target for Cancer Therapy," British Journal of Pharmacology, Vol. 14, No. 3, 2006, pp. 7239-7248. doi:10.1038/sj.bjp.0706556

[24] F. Schwizer, "Cationic Amphiphilic Peptides with Cancer-Selective Toxicity," European Journal of Pharmacology, Vol. 625, No. 1, 2009, pp. 190-194. doi:10.1016/j.ejphar.2009.08.043

[25] D. C. Pimenta and I. Lebrun, "Cryptides: Buried Secrets in Proteins," Peptides, Vol. 28, No. 12, 2007, pp. 24032410.

[26] D. J. Autelitano, A. Rajic, A. I. Smith, M. C. Berndt, L. L. Ilag and M. Vadas, "The Cryptome: A Subset of the Proteome, Comprising Cryptic Peptides with Distinct Bioactivities," Drug Discovery Today, Vol. 11, No. 7-8, 2006, pp. 306-314.

[27] B. Fadnes, O. Rekdal and L. Uhlin-Hansen, "The Anticancer Activity of Lytic Peptides Is Inhibited by Heparin Sulfate on the Surface of the Tumor Cells," BMC Cancer, Vol. 15, No. 9, 2006, pp. 1-13. doi:10.1186/1471-2407-9-183

[28] N. Papo and Y. Shai, "Host Defense Peptides as New Weapons in Cancer Treatment," Cellular and Molecular Life Sciences, Vol. 62, No. 7-8, 2005, pp. 784-790. doi:10.1007/s00018-005-4560-2

[29] S. K. Bhutia and T. K. Maiti, "Targeting Tumor with Peptides from Natural Sources," Trends Biotechnology, Vol. 26, No. 4, 2008, pp. 210-217.

[30] M. Wieczorek, H. Jenssen, J. Kindrachuk, W. R. P. Scott, M. Elliott, K. Hilpert, J. T. J. Cheng, R. E. W. Hancock and S. K. Straus, "Structural Studies of a Peptide with Immune Modulating and Direct Antimicrobial Activity," Chemistry Biology, Vol. 17, No. 9, 2010, pp. 970-980. doi:10.1016/i.chembiol.2010.07.007

[31] P. W. Soballe, W. L. Maloy, M. L. Myrga, L. S. Jacob and M. Herlyn, "Experimental Local Therapy of Human Melanoma with Lytic Magainin Peptides," International Journal Cancer, Vol. 60, No. 2, 1995, pp. 280-284. doi:10.1002/ijc.2910600225

[32] R. E. W. Hancock and H. G. Sahi, "Antimicrobial and Host-Defense Peptides as New Anti-Infective Therapeutic Strategies," Nature Biotechnology, Vol. 24, No. 12, 2006, pp. 1551-1557. doi:10.1038/nbt1267

[33] D. R. Pfeiffer, T. I. Gudz, A. S. Novgorodov and W. L. Ferdahl, "The Peptide Mastoparan Is a Potent Facilitator of the Mitochondrial Permeability Transition," Journal of Biological Chemistry, Vol. 270, No. 9, 1995, pp. 49234932. doi:10.1074/jbc.270.9.4923

[34] Y. Yamada, Y. Shinohara, T. Kakudo, S. C. S. Futaki, H. Kamiya and H. Harashima, "Mitochondrial Delivery of Mastoparan with Transferrin Liposomes Equipped with a pH-Sensitive Fusogenic Peptide for Selective Cancer Therapy," International Journal of Pharmaceutics, Vol. 
303, No. 1-2, 2005, pp. 1-7.

[35] P. Costantini, E. Jacotot, D. Decaudin and G. Kroemer, "Mitochondrion as a Novel Target of Anticancer Chemo- therapy," Journal of National Cancer Institute, Vol. 92, No. 13, 2000, pp. 1042-1053. doi:10.1093/jnci/92.13.1042 